\title{
Internal and Contextual Factors, Knowledge Processes and Performance: from the Chinese Provider's
}

\section{Perspective}

\author{
Shizhong Ai ${ }^{\mathrm{a}, \mathrm{b},{ }^{*}}$, Rong Du ${ }^{\mathrm{a}}$, Pamela Abbott ${ }^{\mathrm{c}}$, Yingqin Zheng ${ }^{\mathrm{d}}$ \\ ${ }^{a}$ School of Economics and Management, Xidian University, Xi'an, Shaanxi, China \\ ${ }^{b}$ School of Computer Science, Xidian University, Xi'an, Shaanxi, China \\ ${ }^{c}$ Department of Information Systems and Computing, Brunel University, UK \\ ${ }^{d}$ Center of Computing and Social Responsibility, De Montfort University, UK
}

\begin{abstract}
This paper explores the influences of two internal factors, i.e. supplier team's IT-based skills and communication with client's team, and two contextual factors, i.e. supplier team's understanding of client's culture and collaboration with client's team, on knowledge processes and performance in global sourcing of IT services from the Chinese provider's perspective. Knowledge processes are characterized by knowledge sharing, knowledgebased coordination and expertise management, and performance is measured by product success and personal satisfaction. Data have been collected in 13 companies in Xi'an Software Park, with 26 in-depth, semi-structured interviews held with top and middle managers, and 200 structured questionnaires distributed to knowledge workers who are involved in global sourcing projects. The results indicate that supplier team's IT-based skills, communication with client's team, cultural understanding of client's culture and collaboration with client's team are positively associated with knowledge process and performance. Also, knowledge sharing, knowledge-based coordination and expertise management are found to be crucial for those influential factors to function positively and contribute to the performance. The findings of this study suggest that the effects of key factors on knowledge processes and performance in global sourcing of IT services appear to transcend the social and cultural differences; however, contextual factors seem to have more significant influences on knowledge processes and performance in global sourcing of IT services.
\end{abstract}

Keywords: knowledge processes; performance; global sourcing; IT services; Chinese provider 


\section{Introduction}

Some studies have paid attention to knowledge processes in globally distributed contexts, which typically occurs in the form of knowledge transfer/sharing, knowledge-based coordination, and expertise management (Rottman, 2008; Kotlarsky, Oshri, \& Van Fenema, 2008). Research findings show that global sourcing of IT services should be treated as a context-dependent scenario (Oshri, Kotlarsky, \& Willcocks, 2008) where cultural understanding should be considered (e.g., Seliem et al., 2003; Aharoni \& Burton, 1994; Rosenzweig, 1994; Deans et al., 1991; Ein-Dor et al., 1993). However, few empirical studies are concerned with the impacts of cultural understanding on a provider's communication and knowledge processes or have associated it with performance in global sourcing of IT services. Furthermore, most of extant research has relied on data gathered from Western cultures (e.g., Graf and Mudambi 2005, Heeks and Nicholson 2004, Carmel 2003) or from a client's perspective (Han et al. 2008). Yet, research findings obtained in Western cultures cannot be generalized to other cultures, since the cultural distance between the West and the East makes the intercultural interaction/trust between them a critical issue (Li, 209).

Although many investigations have emphasized the possible impacts of cultural differences (e.g., Straub et al., 2002; Dasgupta et al., 1999; Watson et al., 1997; Al-Khaldi \& Wallace, 1999; Hassan, 1994; Wetherbe, Vitalari, \& Milner, 1994), few empirical studies on the impacts of cultural difference have been undertaken from the perspective of Chinese provider in global sourcing of IT services. Therefore, it is imperative to broaden the understanding of cultural impact on knowledge processes and performance in global sourcing by conducting investigations in the Chinese context.

To meet this need, this paper will look at knowledge processes and performance in global sourcing of IT services from the Chinese provider's perspective in a Chinese setting, exploring the influences of two internal factors, i.e. the supplier team's IT-based skills and communication with the client's team, and two contextual factors, i.e. the supplier team's understanding of the client's culture and collaboration with the client's team. The purpose of this paper is to report on the results of a joint investigation that used both interviews and questionnaire surveys. The findings in this study should have implications for IT services suppliers in both China and other developing countries, to the MNCs/global corporations who are engaging or wishing to engage with business in China, and to IT services clients all around the world. The implications should enhance the understanding of knowledge processes in global information management in general and in global sourcing of IT services in particular. 
The remainder of the paper is organized as follows. First, the constructs are introduced and a research model and some hypotheses are proposed. Then, the methodologies are presented. After that, the results of data analysis are shown and explained. Finally, the findings and their implications are concluded.

\section{Constructs, research model and hypotheses}

China is becoming involved in providing IT and IT-enabled services to meet growing global demand. These services include information systems development, maintenance and operation generally referred to as IT services, and IT-enabled non-core business processes. Global sourcing of IT services provided in China typically includes coding, systems integration, data mining, network management, call centers, back office work and document management, etc. In this study we use the term global sourcing of IT services to cover all the above areas. Previous research suggests that a number of factors are thought to influence success in global sourcing of IT services in developing countries from both the firm and country levels of analysis.

The country level factors may be useful to some degree in establishing broad pre-requisites for potential success in China's service outsourcing industry, but one area that is often neglected is the influence of social contextual factors such as culture, history and institutional settings in creating an environment that may provide uniquely advantageous aspects that can be exploited. Krishna et al. (2000), for example, demonstrate convincingly how India's social and historical heritage proved invaluable in providing a basis for their well-documented successes in software export. Compared with India, China is intrinsically more distinct from Western countries in terms of its social contextual factors. As a result, China's major client to date is Japan. Hence, there is large room for China to increase its share of the global sourcing market from Western clients. The challenge involved in this development may be Chinese suppliers' understanding of clients' cultures and collaboration with clients.

\subsection{Contextual and internal factors influencing global sourcing}

From the perspective of service providers, factors influencing global sourcing can be classified into two categories: contextual factors and internal factors. Contextual factors roughly correspond to Krishna et al.'s (2000) considerations with regard to social and historical heritage. Heeks and Nicholson (2004), and Carmel (2003) have addressed these contextual factors in their studies. History of trade linkages, geographical position to clientele, 
4

cultural issues and political issues are some examples of contextual factors. All the above factors can affect and be embodied in the collaboration between supplier's team and client's team, and the two sides' intercultural understanding. Among these contextual factors, from the perspective of service providers, the supplier team's cultural understanding of the client's culture (CT) and collaboration with client's team (CB) can be two major factors that are related to the client-specific capabilities defined by Levina and Ross (2003).

Internal factors represent some technological and organizational factors, which were addressed by Kotlarsky et al. (2008) as technology-based mechanisms and organization design mechanisms, and were defined by Levina and Ross (2003) as process capabilities and human resource capabilities. Supplier's human resources, IT-based skills, communication skills, quality standards, and core knowledge/expertise are some examples of internal factors. Among these internal factors, the supplier team's IT-based skills (IS) and communication with the client's team (CM) are two major factors that influence the success in global sourcing.

In addition to contextual factors and internal, attention should also be paid to other environmental factors, some of which were addressed by Heeks and Nicholson (2004) as local market demand and characteristics of the national software industry, others described by Graf and Mudambi (2005) as appropriate infrastructure and potential markets. But, to simplify the research model, in this paper we do not address those environmental factors.

\subsection{Knowledge processes in global sourcing}

According to Kotlarsky et al. (2008), knowledge processes in globally distributed contexts, such as global sourcing projects, represent the value an organization generates from engaging in, improving, and magnifying knowledge work by collaborating across distances, time zones, and cultures. Following this definition, knowledge processes are characterized by knowledge transfer/knowledge sharing, knowledge-based coordination and expertise management.

Knowledge sharing (KS) is thought to be helpful to improve the effectiveness of group work (Storck 2000). In globally distributed project teams like those in global sourcing, when sharing knowledge, there is a need for team members to know whom to contact about what in this specific organization. To meet this need, transactive memory has been developed. Wegner (1987) defined transactive memory as the knowledge possessed by group members coupled with an awareness of who knows what. Another concept that was proposed to describe knowledge sharing is 
collective knowledge. Collective knowledge, according to Grant (1996), comprises elements of knowledge that are common to all members of an organization. Although a range of communication tools (e.g., Groupware applications, knowledge repositories, videoconference, online chat, email), which support knowledge sharing across remote locations, can be used in globally dispersed teams in global sourcing, such technical solutions are not sufficient. This fact emphasizes the need for further examination of socially constructed elements involved in knowledge sharing as complementary mechanisms to existing technical solutions. Therefore, it is meaningful to relate knowledge sharing to some social aspects such as cultural understanding and collaboration.

Knowledge-based coordination (KC) is embodied in some coordination mechanisms. Kotlarsky et al. (2008) distinguish the following categories of coordination mechanisms: organization design mechanisms, work-based mechanisms, technology-based mechanisms, and social mechanisms. Organization design mechanisms refer to formal role structures, such as hierarchies, linking pins, teams, and direct contacts. Work-based mechanisms focus on the specific structuring of tasks to be accomplished by an organization. Technology-based mechanisms are defined in terms of information capturing, processing, storage, and exchange. Social mechanisms encompass communication activities, working relationships, and social cognition. With these mechanisms combined together, globally distributed organizations in global sourcing can hold a knowledge-based perspective on coordination and achieve successful knowledge-based coordination in their knowledge processes, amplifying knowledge, making knowledge explicit and facilitating knowledge flows.

Faraj and Sproull (2000) define expertise as the possession of specialized knowledge and skills, such as technical and domain knowledge. Fitzpatrick (2003) considers expertise to be context-dependent, embedded in practice. Oshri et al. (2008) describe expertise as the ability to act knowledgably within a specific domain of application, similar to know-how or competence, closely related to the notion of knowing in practice. All the above views have a common idea that expertise is fairly relevant to knowledge and knowledge application, thus, expertise management (EM) constitutes a necessary part in knowledge processes in global sourcing. Through expertise management, service providers can integrate diverse domains of expertise to facilitate knowledge transfer between onsite and offshore teams and across projects.

One may ask why collaboration with client's team (CB) should be classified as the contextual factor and communication with client's team $(\mathrm{CM})$ as the internal factor. The reason is that $\mathrm{CB}$ is more social and relevant to 
6

social and historical contexts while CM is more technological and irrelevant to social and historical contexts. CB and CM may have some overlap with knowledge-based coordination (KC), however, $\mathrm{CB}$ and $\mathrm{CM}$ are closer to antecedent variables like IS and CT than to mediating variables like $\mathrm{KC}$ if they are considered as process variables. Therefore, we think the overlap between $\mathrm{CB}$ and $\mathrm{CM}$ with $\mathrm{KC}$ is negligible.

\subsection{Performance in global sourcing}

Performance in global sourcing has a variety of dimensions. Hoegl and Gemuenden (2001) consider either product success or a desired performance of a distributed team as measures for success in innovative projects. Various indicators, such as sales growth, on time product delivery and low cost, can represent product success. Kotlarsky and Oshri (2008) defined product success as the achievement of project objectives, either based on market or company data, or based on project participants' perception of product success. A desired performance of a distributed team can be a people-related outcome (Hoegl and Gemuenden, 2001) which entails meeting team members' psychological needs. So there should be some level of personal satisfaction (Kotlarsky and Oshri, 2008) that motivates individuals and teams to continue their engagement in collaborative globally distributed work. Hence, we use both product success and personal satisfaction to measure outcome in global sourcing (OO).

\subsection{Research model}

Contextual factors and internal factors are thought to impact knowledge processes in global sourcing, which mediates the effects of those factors on outcome in global sourcing. Based on the extant literature and our pilot interviews, which will be detailed later in the section of Methodologies, we have identified the supplier team's cultural understanding of the client's culture (CT) and collaboration with the client's team (CB) as two major contextual factors, and the supplier team's IT-based skills (IS) and communication with the client's team (CM) as two major internal factors. We use knowledge sharing (KS), knowledge-based coordination (KC) and expertise management (EM) to measure knowledge processes. Performance in global sourcing is represented by outcome in global sourcing $(\mathrm{OO})$, measured by question items on product success and personal satisfaction.

On the basis of the constructs addressed above, we build a conceptual model of the relationship between major influential factors and knowledge processes and performance in global sourcing. The model is shown in Fig. 1. 
Insert Fig. 1 about here.

\subsection{Research hypotheses}

There is a general premise in global sourcing literature that the better the supplier's core capabilities, the greater will be the success in global sourcing (e.g. Levina and Ross, 2003; Feeny et al., 2005). Following this premise, we hypothesize:

H1: The better a supplier team's IT-based skills, the greater the success in global sourcing.

H2: The better a supplier team's communication with the client's team, the greater the success in global sourcing. Intuitively, a supplier team's good IT-based skills and well communication with the client's team may improve knowledge processes by positively impacting knowledge sharing, knowledge-based coordination and expertise management. Therefore, we hypothesize

H3: The better a supplier team's IT-based skills, the better the knowledge sharing in global sourcing arrangements.

H4: The better a supplier team's IT-based skills, the better the knowledge-based coordination in global sourcing arrangements.

H5: The better a supplier team's IT-based skills, the better the expertise management in global sourcing arrangements.

H6: The better a supplier team's communication with the client's team, the better the knowledge sharing in global sourcing arrangements.

H7: The better a supplier team's communication with the client's team, the better the knowledge-based coordination in global sourcing arrangements.

H8: The better a supplier team's communication with the client's team, the better the expertise management in global sourcing arrangements.

In addition to core capabilities of providers, researchers claim that contextual factors influence the supplier team's communication with the client's team and the outcome of the global sourcing relationship (e.g. Krishna et al., 2000). Therefore, we pose the following hypotheses: 
8

H9: The better a supplier team's cultural understanding of the client's culture, the better the supplier's communication with the client's team in global sourcing arrangements.

H10: The better a supplier team's collaboration with the client's team, the better the supplier's communication with the client's team in global sourcing arrangements.

H11: The better a supplier team's cultural understanding of the client's culture, the greater the success in global sourcing arrangements.

H12: The better a supplier team's collaboration with the client's team, the greater the success in global sourcing arrangements.

Some researchers argue that knowledge processes in global sourcing projects represent the value an organization generates from engaging in, improving, and magnifying knowledge work, and as a result, greater success may be achieved in global sourcing by realizing benefits of knowledge creation and exploitation embedded in knowledge processes (e.g., Kotlarsky et al., 2008; Oshri et al., 2009). Therefore, we propose the following hypotheses.

H13: The better a supplier team's cultural understanding of the client's culture, the better the knowledge sharing in global sourcing arrangements.

H14: The better a supplier team's cultural understanding of the client's culture, the better the knowledge-based coordination in global sourcing arrangements.

H15: The better a supplier team's cultural understanding of the client's culture, the better the expertise management in global sourcing arrangements.

H16: The better a supplier team's collaboration with the client's team, the better the knowledge sharing in global sourcing arrangements.

H17: The better a supplier team's collaboration with the client's team, the better the knowledge-based coordination in global sourcing arrangements.

H18: The better a supplier team's collaboration with the client's team, the better the expertise management in global sourcing arrangements.

H19: The better the knowledge sharing, the greater the success in global sourcing.

H20: The better the knowledge-based coordination, the greater the success in global sourcing.

H21: The better the expertise management, the greater the success in global sourcing. 


\section{Mthodologies}

\subsection{Sampling}

Thirteen companies in Xi'an Software Park have been chosen as our sample. Xi'an is the capital city of Shaanxi Province, a famous metropolis not only for its historical and cultural resorts, but also for its college education, science and technology, and high-tech industries. It claims to have a high software industry maturity and sufficient qualified software talent. Moreover, the living cost index in Xi'an is lower than most of the major outsourcing hubs in China. Furthermore, the local government has successively released preferential policies to attract overseas Chinese Diaspora and foreign investments. For these reasons, lots of IT and IT-enabled services firms engaged in global sourcing have been set up in Xi'an. Therefore, Xi'an City can represent the typical context of global sourcing in China. The Xi'an Software Park is an industrial site for IT and IT-enabled services firms engaged in global sourcing. It is a professional technology park concerned with developing software and service outsourcing industries. The park has been appraised as a national software industry base and national software export base, and a demonstrational area of national service outsourcing base. It comprises $90 \%$ of the enterprises engaging in software and service outsourcing in Xi'an. A group of world-renowned corporations have set up their units in the Xi'an Software Park. There are also some firms set up by Taiwan companies and those by well-known domestic companies, all experiencing considerable growth. Hence, the firms in Xi'an Software Park, to some degree, can provide relevant data to address, from a Chinese perspective, the research issues raised in this study.

\subsection{Data collection}

The research team is global, collaborative and multi-cultural in composition and consists of: 3 native Chinese speaking researchers, two based in Xi' an city and the other in the UK; 2 native English speaking researchers based in the UK; and 10 native Chinese speaking postgraduate students based in Xi'an supervised by the Xi'an-based researchers. Both face-to-face interviews and questionnaire surveys were used in the research. The interviews were undertaken to obtain the profiles of the companies, to identify constructs and to develop question items that measure constructs, and to generate fundamental ideas on research model(s) and hypotheses. The surveys were conducted to collect quantitative data, to test the reliability and validity of the question items and scales, and to test the model(s) and hypotheses. 
10

In this study, two visits were made by the UK-based researchers together with the local ones to the site for faceto-face interviews, each separated by a six-month interval; further visits were made by the Xi'an-based researchers and their students to the site for administering the questionnaire surveys. Thirteen indigenous and multi-national companies, whose organizational structures reflected a mixture of expatriate and local management, were chosen as participants in the research. Assistance in recruitment of the candidate companies was obtained from the management of the software park.

In-depth face-to-face semi-structured interviews lasting between 1 to 1.5 hours were held with approximately 26 mid to senior level managers within these companies. The interview protocol addressed questions concerning the firms' capability to engage in successful sourcing relationships, their knowledge management processes, crosscultural issues encountered and also the issues arising when attempting to develop client relationships. Interviewing two levels of management allowed for gathering multiple perspectives which could then triangulated with the survey data. The Chinese language interviews were translated into English. The English translations were proof-read and checked by the UK-based Chinese researcher for accuracy. Interviews taken in English were transcribed. The transcriptions are used to identify constructs and to develop question items, and to build research model before questionnaire surveys.

Questionnaire surveys were conducted within 13 participant companies involving 200 respondents. A questionnaire (in both Chinese and English language for each question) was designed collaboratively by the major researchers through regular Skype meetings, on the basis of the interviews held in the first visit and relevant literature review. Twenty-three questions were designed explicitly to collect data from employees participating in global sourcing projects. Of these, a few questions dealt with general data on the respondents and their extant projects, while the majority of the questions focused on the issues raised in this paper, i.e. supplier team's IT-based skills, communication with client's team, understanding of client's culture, collaboration with client's team, knowledge sharing, knowledge-based coordination, expertise management, and outcome in global sourcing. Most of these questions used 5-point Likert scale to measure the research variables, which will be addressed later. The major scales and items were based on the ones that were adopted in earlier studies and considered to have high content validity. The items were revised to suit this research in the specific context of China and some new items were designed on the basis of focus group discussions. Earlier versions of the questionnaire were discussed through the Skype meetings, 
piloted using a number of postgraduate students at Xidian University, in Xi'an, and revised before the final version was formulated. In total, 200 questionnaires were distributed to 13 companies; 160 were returned out of which 148 were valid.

\subsection{Data analysis}

Attempting to test the research model shown in Figure 1 and the proposed hypotheses, based on the evidence observed in the pilot interviews and the constructs identified, we defined research variables and question items for measurement. After questionnaire surveys, we conducted a statistical analysis of the data collected in the questionnaire survey.

As shown in Table 1, from the perspective of suppliers, there are eight research variables, namely, supplier team's IT-based skills (IS), communication with client's team (CM), cultural understanding of client's culture (CT), collaboration with client's team (CB), and knowledge sharing (KS), knowledge-based coordination (KC), expertise management (EM), and outcome in global sourcing (OO).

Eleven question items were used to measure IT-based skills (IS), and 5 items and 9 items respectively to measure supplier team's communication with client's team $(\mathrm{CM})$ and collaboration with client's team (CB). Items for IS, CM and CB were revised on the basis of Han et al.'s (2008) scales. Based on the pilot interviews, we designed 10 items to measure supplier's cultural understanding of client's culture. Based on the pilot interviews and relevant literature (e.g., Kotlarsky et al. 2008), we designed 29 items to measure knowledge sharing (KS), knowledge-based coordination (KC), and expertise management (EM). Outcome in global sourcing (OO) is defined as the extent to which a global sourcing project achieves success in the dimensions of product success and personal satisfaction. Based on Han et al.'s (2008) scales, eight question items were adopted to measure the outcome in global sourcing.

To measure the internal consistency and the reliability of the multi-item scale in the questionnaire, we used Cronbach alpha test. As show in Table 1, the alpha levels for 8 research variables are all higher than 0.700 , which is the recommended minimum acceptable level for reliability in basic research (Ives \& Olson, 1984), and the overall alpha level for the instrument is 0.944 , also higher than 0.70 . These figures mean the internal reliability of the questionnaire items is good and the questionnaire is reliable. 
12

Insert Table 1 about here.

\section{Results}

In the following we will show and explain the results of correlation analysis derived by using SPSS software (Table 2) and the hypotheses testing results in particular (Table 3).

Insert Table 2 about here.

Table 2 shows the following major results of correlation analysis:

1) There are significant positive correlations (with correlation coefficients $.440, .420$, and .466 respectively) between IT-based skills (represented by IS) and knowledge sharing (KS), knowledge-based coordination (KC) and expertise management (EM). A less significant positive correlation (with a correlation coefficient of .373) exists between ITbased skills (IS) and outcome in global sourcing (OO). This implies that a supplier team's IT-based skills contribute more to knowledge processes (represented by $\mathrm{KS}, \mathrm{KC}$, and EM) than directly to outcome in global sourcing of IT services. In other words, a supplier team's IT-based skills are not only imperative to the outcome of global sourcing of IT services, but also necessary to knowledge processes, which mediate the relationship between supplier's ITbased skills and outcome in global sourcing of IT services.

2) There are positive correlations (with correlation coefficients .361 , and .387 respectively) between supplier team's communication with client's team (CM) and knowledge sharing (KS) and knowledge-based coordination (KC). A less significant positive correlation (with correlation coefficient .270) exists between supplier team's communication with client's team $(\mathrm{CM})$ and outcome in global sourcing $(\mathrm{OO})$. This implies that a supplier team's communication with the client's team (CM) contributes more to knowledge sharing and knowledge-based coordination than directly to the outcome in global sourcing of IT services. This means that a supplier team's communication with the client's team is more important for some knowledge processes to take place in global sourcing of IT services, which indirectly contributes to the outcome in global sourcing of IT services. In other words, knowledge processes mediate 
the relationship between the supplier team's communication with the client's team and outcome in global sourcing of IT services.

3) Significant positive correlations (with correlation coefficients .632, and .577 respectively) exist between knowledgebased coordination (KC), expertise management (EM) and outcome in global sourcing of IT services, while a slight positive correlation (with a correlation coefficient of .182) can be seen between knowledge sharing (KS) and outcome in global sourcing of IT services. This implies that knowledge processes contribute significantly to outcome in global sourcing of IT services, and better knowledge processes lead to better outcome in global sourcing of IT services. Together with Results 1 and 2, therefore, we can see that knowledge processes, characterized by knowledge sharing (KS), knowledge-based coordination (KC) and expertise management (EM) have important mediating roles in transforming supplier's internal capabilities, such as supplier team's IT-based skills and communication with client team, into success in global sourcing of IT services.

4) Significant positive correlations exist between a supplier team's cultural understanding of client's culture (CT) and collaboration with the client's team (CB), and a supplier team's communication with the client's team $(\mathrm{CM})$, with correlation coefficients respectively being .544 and .614 , larger than .270 , the correlation coefficient between supplier team's communication with client's team (CM) and outcome in global sourcing (OO). This implies that contextual factors, such as supplier team's cultural understanding of client's culture (CT) and collaboration with client's team (CB) contribute significantly to a supplier team's communication with the client's team $(\mathrm{CM})$, which then contributes to outcome in global sourcing of IT services. This means that contextual factors are very important for the supplier team's communication with the client's team. In other words, the supplier team's cultural understanding of the client's culture and collaboration with the client's team both moderate the relationship between the supplier team's communication with the client's team and the outcome in global sourcing of IT services.

5) Positive correlations (with correlation coefficients respectively being .163 and .517) exist between supplier team's cultural understanding of client's culture (CT) and collaboration with client's team (CB), and outcome in global sourcing (OO). Also, there are positive correlations between supplier team's cultural understanding of client's culture (CT) and collaboration with client's team (CB), and knowledge sharing (KS) and knowledge-based coordination (KC), with correlation coefficients respectively being .292, .210, .458, and .564. This implies that contextual factors, such as the supplier team's cultural understanding of the client's culture and collaboration with the client's team, 
14

contribute to knowledge processes at the same time when they contribute to outcome in global sourcing. This means that contextual factors are also very important for knowledge processes to take place. Together with Result 4 , therefore, we can see that, contextual factors, i.e. supplier team's cultural understanding of the client's culture and collaboration with client's team, are important to success in global sourcing of IT services.

The research hypotheses were tested using Pearson's correlation. Table 3 shows a summary of the hypotheses testing results. Except for $H 15$, all the other hypotheses were tested to be true. We will explain the findings embedded in these results later.

Insert Table 3 about here.

\section{Discussion}

From the above major results of correlation analysis we can derive the following findings: 1) Knowledge processes represented by knowledge sharing, knowledge-based coordination and expertise management, have important mediating roles in transforming offshore supplier's internal capabilities into good outcome in global sourcing; 2) Contextual factors in globally distributed project teams in global sourcing, such as a supplier team's cultural understanding of the client's culture and collaboration with the client's team, play important roles that influence the success of global sourcing both directly and indirectly through knowledge processes in dispersed project teams. These findings imply that major contextual factors like the supplier team's cultural understanding of the client and collaboration with the client's team play important roles that affect the success of global sourcing through knowledge processes in dispersed project teams.

From the hypotheses testing results we can see most (20) of the hypotheses (21) proposed in this study were found to be supported. The acceptance of $H 1$ and $H 2$ reveals that as major internal factors, the supplier team's ITbased skills and communication with the client's team influence the outcome in global sourcing; however the impact of IT-based skills were found to be slightly bigger than that of communication. This finding is not surprising in terms that IT-based skill is harder and more imperative whereas communication is softer and less essential, and some suppliers we visited tend to emphasize IT-based skills but less on soft skills. It reflects the characteristics of a certain 
type of suppliers and indicates that these suppliers are still at the lower end of the value chain of offshore service outsourcing. In other words, they tend to undertake projects that are IT intensive but require limited interactions with clients. However, there are other suppliers in China which are able to take up more knowledge-intensive projects, which require further research.

The results of testing $H 9$ and $H 10$ show that as major contextual factors, the supplier team's cultural understanding of and collaboration with the client's team significantly improves the supplier team's communication with the client's team in global sourcing. This finding implies that Chinese suppliers should focus more on soft sides, like cultural understanding of the client's team and collaboration with it, to improve communication with the client in global sourcing relationship, since China is seen to be more culturally distant than other national cultures (Li, 2009). This finding is meaningful especially to offshore service providers and clients whose cultural distance is larger than that of onshore providers and clients.

The acceptance of $H 11$ and $H 12$ shows that the supplier team's cultural understanding of, and collaboration with the client's team directly affect the outcome in global sourcing. This finding echoes the findings that David et al. (2008) reported on the basis of their investigations in GLOBALIS' distributed sites in Ireland and India. This finding also supports the findings of Kotlarsky and Oshri (2008) who state that a supplier team's cultural understanding of, and collaboration with, the client's team can strengthen social ties between supplier and client teams in the dimensions of rapport and trust. However, $H 11$ and $H 12$ also imply that the influence of cultural understanding is not as significant as that of collaboration. The reason for this may be that Chinese suppliers felt that they do not themselves perceive the cultural understanding of the client's culture because of their own acculturation processes. We report elsewhere on these findings in detail.

The results of testing $H 13-H 14$ and $H 16-H 18$ reveal that the supplier team's cultural understanding of, and collaboration with, the client's team can enhance knowledge sharing, knowledge-based coordination and expertise management in global sourcing. This finding is consistent with Rottman's (2008) finding that a supplier team's cultural understanding of, and collaboration with, the client's team can increase social capital in the cognitive and relational dimensions respectively. This finding also supports Evaristo's (2003) general views. It is meaningful to offshore service providers in general and to the Chinese suppliers and Western clients in particular because intercultural trust between those from the Chinese ethnic culture and Western cultures is a challenging issue. Similar 
16

to the results on $H 11$ and $H 12$, the influence of cultural understanding on knowledge processes is not as significant as that of collaboration. We think the reason is the same as stated for $H 11$ and $H 12$.

The acceptance of H19-H21 shows that knowledge sharing, knowledge-based coordination and expertise management have positive impacts on outcome in global sourcing. This finding is in agreement with those of many other previous studies (e.g. Kotlarsky and Oshri, 2008; Goodman and Darr, 1998; Majchrzak et al., 2000). This finding has special meaning for global sourcing of IT services in which considerable knowledge and expertise are generated and accumulated and exploited in project teams. The results of testing $H 19-H 21$ also reveal that the impact of knowledge sharing is much less than that of knowledge-based coordination and expertise management. There are two possible reasons. First, knowledge sharing between Chinese supplier teams and their offshore client teams is not mature. Second, some Chinese people are confused by the paradox of knowledge sharing and intellectual property protection.

It is noticeable that evidence in this study does not support H15. This result is inconsistent with our expectation and contradicts with the finding of Oshri et al. (2008). We think there are two possible reasons: 1) lower level managers and employees who participated in the surveys do not have a clear understanding of expertise management as would their top managers; 2) firms surveyed do not have a mature mechanism for expertise management. This finding implies that Chinese suppliers have a long journey to enhance their expertise management in providing global sourcing services.

\section{Conclusions and implications}

The hypothesized relationships between internal factors (supplier team's IT-based skills and communication with client's team), contextual factors (supplier team's cultural understanding of client's culture and collaboration with client's team), knowledge processes (knowledge sharing, knowledge-based coordination and expertise management), and performance (outcome in global sourcing) in the research model of this study have been empirically supported. The findings in this study substantiate the importance of supplier team's IT-based skills, communication with client's team, cultural understanding of client's culture and collaboration with client's team for Chinese service providers to improve knowledge sharing, knowledge-based coordination and expertise management in service providing processes and thereby achieving success in global sourcing. 
This study was conducted through a Sino-UK joint investigation by a cross-cultural research team. 26 in-depth, semi-structured interviews were held and 200 questionnaires were distributed in 13 companies in Xi'an Software Park, a typical Chinese outsourcing hub. The evidence provided in this study came from an environment that is socially and culturally different from environments in which most prior global sourcing research has been undertaken, e.g., in Western countries like the U.K., U.S, Canada and Ireland, or in countries like India and Philippines who have historical colonial linkages with the West. The findings of this investigation suggest that the effect of key factors, namely the supplier team's IT-based skills, communication with the client's team, cultural understanding of the client's culture and collaboration with the client's team, on knowledge process and success of global sourcing appears to be common in spite of social and cultural differences in different contexts. But the effect of a supplier team's cultural understanding of the client's culture and collaboration with the client's team on knowledge processes and outcome in global sourcing provided by Chinese suppliers was found to be significant. This implies that cultural understanding of, and collaboration with, the client's team are more important in the countries like China who may have a bigger cultural difference from their client countries than some other countries like India and the Philippines. These findings help to enhance our understanding of knowledge processes in global information management in general and in global sourcing of IT services in particular. They provide some empirical evidence on the international validity of findings from previous studies in Western environments and enhance efforts to build a general theory of global outsourcing and offshoring. Moreover, we think this study is unique in that it is based on empirical data and quantitative analysis of the data, because very little previous work, to our knowledge, actually used empirical data, i.e. numerical quantitative analysis to come up with their models and findings, in other words, most of the previous studies were based on qualitative analysis of interview data. The findings from this study have implications not only for the global sourcing of IT services suppliers in China, but also for the global sourcing of IT services suppliers in other developing countries, the MNCs/global corporations who engage or wish to engage with Chinese firms, and the global sourcing of IT services all around the world.

Due to the non-random sample used in this investigation, generalization of its findings to other Chinese service suppliers involved in global sourcing and beyond must be made cautiously. Replications of this study in China and in other countries are needed. To further understand the effects of other factors, other variables may be added to the research model used in this study (Figure 1) as possible impacting factors of knowledge processes and performance 
18

in global sourcing of IT services, including cultural distance and educational structure. Therefore, additional studies of contextual factors and their impacts on knowledge processes and performance in global outsourcing and offshoring in different cultures and countries are indispensable. The accumulation of such studies enables global outsourcing and offshoring researchers to make comparisons and to integrate findings into frameworks that enhance the understanding of the influences of impacting factors on knowledge processes and performance in global sourcing.

\section{Acknowledgments}

We are grateful to the people we interviewed in Xi'an Software Park and the people who helped us with the arrangements. We appreciate our respondents who answered our questionnaires. We owe much to Professor Leslie Willcocks for his great contributions to this research. Thanks to the research students who participated in this project. This research is supported by the National Natural Science Foundation of China through grant 70871096, Program for Humanity and Social Science Research through grant 09YJA630126, and Program for New Century Excellent Talents in University in China through grant NCET-08-0812. It is also supported by Research Development Fund in Brunel University, the UK.

\section{References}

Abbott, P., Zheng, Y., Du, R. and Willcocks, L.P. (2010). From Boundary Spanning to Creolization: Cross-cultural Strategies from the Offshore Provider's Perspective. Proceedings of the Americas Conference on Information Systems, Lima, Peru, August 12-15, 2010.

Analysis International. (2008). analysis international-china offshore software outsourcing market reached CNY 4.53 billion in Q3 of 2003. Available: http://english.analysys.com.cn/ 3class/detail.php?id=397\&name [27/11/2008, 2008].

Carmel, E. (2003). The new software exporting nations: success factors. The Electronic Journal of Information Systems in Developing Countries, 13(4), 1-11.

ChinaSourcing. (2009). China's service outsourcing contract sales up to 20 billion US dollars in 2009. Available: http://chinasourcing.mofcom.gov.cn/content2.jsp?id=65836 [2010-02-08, 2009] 
David, G.C., Chand, D., Newell, S.N., and Resende-Santos, J. (2008). Integrated collaboration across distributed sites: the perils of process and the promise of practice. In Oshri, I., Kotlarsky, J., and Willcocks, L.P. (Ed.) Outsourcing Global Services: Knowledge, Innovation and Social Capital. Cromwell Press Ltd, 127-150.

Graf, M. and Mudambi, S.M. (2005). The outsourcing of IT-enabled business processes: a conceptual model of the location decision. Journal of International Management, 11(2), 253-268.

Evaristo, R. (2003). The management of distributed projects across cultures. Journal of Global Information Management, 11(4), 58-70.

Faraj, S. and Sproull, L. (2000). Coordination expertise in software development teams. Management Science, 46(12), $1554-1568$.

Feeny, D., Lacity, M., and Willcocks, L.P. (2005). Taking the measure of outsourcing providers. MIT Sloan Management Review, 46(3), 41-48.

Fitzpatrick, G. (2003). Emergent expertise sharing in a new community, in Ackerman et al. (eds) Sharing Expertise: Beyond Knowledge Management, The MIT Press, Cambridge, MA.

Goodman, P.S., and Darr, E.D. (1998). Computer-aided systems and communities: mechanisms for organizational learning in distributed environments. MIS Quarterly, 22(4), 417-440.

Grant, R.M. (1996). Toward a knowledge-based theory of the firm. Strategic Management Journal, 17(Winter), 109-122.

Han, H.s., Lee, J.N., and Seo, Y.W. (2008). Analyzing the impact of a firm's capability on outsourcing success: a process perspective. Information and Management, 45(1), 31-42.

Heeks, R. and Nicholson, B. (2004). Software export success factors and strategies in 'Follower' nations. Competition \& Change, 8(3), 267-303.

Hoegl, M. and Gemuenden, H.G. (2001). Teamwork quality and the success of innovative projects: a theoretical concept and empirical evidence. Organization Science, 12 (4), 435-449.

Hofstede, G. (1980). Culture's Consequences. London, Sage Publications Inc.

Kotlarsky, J. and Oshri, I. (2008). Knowledge sharing, social ties and successful collaboration in globally distributed system development projects. In Kotlarsky, J., Oshri, I. and Fenema, P. (Ed.), Knowledge Processes in Globally Distributed Contexts, Cromwell Press Ltd, UK, 1-23. 
20

Kotlarsky, J. Fenema, P.C., Willcocks, P.W. (2008). Developing a knowledge-based perspective on coordination: the case of global software projects.” In Kotlarsky, J., Oshri, I. and Fenema, P. (Ed.), Knowledge Processes in Globally Distributed Contexts, Cromwell Press Ltd, UK, 74-105.

Kotlarsky, J., Oshri, I., and Fenema, P.C. (2008). Knowledge Processes in Globally Distributed Contexts, Cromwell Press Ltd, UK.

Krishna, S., Ojha, A.K. and Barrett, M. (2000). Competitive advantage in the software industry: an analysis of the indian experience," In: Avgerou, C. and Walsham, G. (Ed), Information technology in context: studies from the perspective of developing countries. Aldershot: Ashgate, 303.

Levina, N. \& Ross, J.W. (2003). From the vendor's perspective: exploring the value proposition in information technology outsourcing. MIS Quarterly, 27 (3), 331-364.

Levina, N. \& Vaast, E. (2005). The emergence of boundary spanning competence in practice: implications for implementation and use of information systems. MIS Quarterly, 29(2), 335-363.

Levina, N. \& Vaast, E. (2006). Turning a community into a market: a practice perspective on information technology use in boundary spanning. Journal of Management Information Systems, 22(4), 13-37.

Levina, N. \& Vaast, E., (2008). Innovating or doing as told? status differences and overlapping boundaries in offshore collaboration. MIS Quarterly, 32(2), 307-332.

Levina, N. and Kane A.A. (2009). Immigrant managers as boundary spanners on offshored software development projects: partners or bosses? Proceedings ACM Workshop on Intercultural Collaboration 2009, Stanford University, Palo Alto, California, USA, February 20-21.

Li, P.P. (2009). Intercultural trust and trust-building: the contexts and strategies of adaptive learning in acculturation. Working paper for FINT Workshop Track IV: Theorizing about Trust across Contexts.

Majchrzak, A., Rice, R.E., King, N., Malhotra, A. and Ba, S. (2000). Computer-mediated inter-organizational knowledgesharing: insights from a virtual team innovating using a collaborative tool. Information Resources Management Journal, 13(1), 44-54.

Mol, M.J. (2007). Outsourcing: design, process and performance, Cambridge: Cambridge University Press.

Nasscom, factsheets. Available: http://www.nasscom.in/Nasscom/templates/ NormalPage.aspx?id= 53615 [27/11/2008, 2008]. 
Oshri, I., Kotlarsky, J., and Willcocks, L.P. (2009). The handbook of global outsourcing and offshoring. Palgrave Macmillan. London.

Oshri, I., Kotlarsky, J., and Willcocks, L.P. (2007). Global software development: exploring socialization in distributed strategic projects. Journal of Strategic Information Systems, 16(1), 25-49.

Oshri, I., Kotlarsky, J., Willcocks, L.P., and Fenema P.C. (2008). Expertise management in a distributed context: the case of offshore information technology outsourcing, In Kotlarsky, J., Oshri, I. and Fenema, P. (Ed.), Knowledge Processes in Globally Distributed Contexts, Cromwell Press Ltd, UK, 106-131.

Qu, Z. and Brocklehurst, M. (2003). What will it take for China to become a competitive force in global sourcing? an analysis of the role of transaction costs in supplier selection. Journal of Information Technology, 18(1), 53.

Rottman, J.W. (2008). Successful knowledge transfer within offshore supplier networks: a case study exploring social capital in strategic alliances. Journal of Information Technology, 23 (1):3-43.

Sahlin-Andersson, K. \& Engwall, L. (2002). The expansion of management knowledge: carriers, flows and sources, Stanford Business Books.

Storck, J. (2000). Knowledge diffusion through 'strategic communities'. Sloan Management Review, 41(2), 63-74.

Wegner, D.M. (1987). Transactive memory: a contemporary analysis of the group mind, in Mullen, G. and Goethals, G. (Ed) Theories of Group Behaviour, Springer Verlag, New York. 
Table 1: Research variables and internal reliability of the questionnaire items

\begin{tabular}{|l|l|l|}
\hline Variable name & Number of items & Alpha reliability \\
\hline Supplier team's IT-based skills (IS) & 11 & 0.891 \\
\hline Communication with client's team (CM) & 5 & 0.747 \\
\hline Cultural understanding of client's culture (CT) & 10 & 0.773 \\
\hline Collaboration with client's team (CB), & 9 & 0.846 \\
\hline Knowledge sharing (KS), & 11 & 0.879 \\
\hline Knowledge-based coordination (KC), & 9 & 0.891 \\
\hline Expertise management (EM) & 9 & 0.876 \\
\hline Outcome in global sourcing (OO) & 8 & 0.834 \\
\hline Overall & 71 & 0.944 \\
\hline
\end{tabular}


Table 2: Results of correlation analysis

\begin{tabular}{|c|c|c|c|c|c|c|c|c|c|}
\hline \multicolumn{10}{|c|}{ Correlations } \\
\hline & & $\mathbf{C M}$ & CT & CB & IS & KS & KC & EM & OO \\
\hline \multirow{3}{*}{$\mathbf{C M}$} & $\begin{array}{l}\text { Pearson } \\
\text { Correlation }\end{array}$ & 1 & $.544(* *)$ & $.614(* *)$ & $.451(* *)$ & $.361(* *)$ & $.387(* *)$ & .119 & $.270(* *)$ \\
\hline & Sig. (2-tailed) & & .000 & .000 & .000 & .000 & .000 & .151 & .001 \\
\hline & $\mathbf{N}$ & 148 & 148 & 148 & 148 & 148 & 148 & 148 & 148 \\
\hline \multirow{3}{*}{ CT } & $\begin{array}{l}\text { Pearson } \\
\text { Correlation }\end{array}$ & $.544(* *)$ & 1 & $.548(* *)$ & $.314(* *)$ & $.292(* *)$ & $.210(*)$ & -.032 & $.163(*)$ \\
\hline & Sig. (2-tailed) & .000 & & .000 & .000 & .000 & .010 & .700 & .048 \\
\hline & $\mathbf{N}$ & 148 & 148 & 148 & 148 & 148 & 148 & 148 & 148 \\
\hline \multirow{3}{*}{ CB } & $\begin{array}{l}\text { Pearson } \\
\text { Correlation }\end{array}$ & $.614(* *)$ & $.548(* *)$ & 1 & $.571(* *)$ & $.458(* *)$ & $.564(* *)$ & $.393(* *)$ & $.517(* *)$ \\
\hline & Sig. (2-tailed) & .000 & .000 & & .000 & .000 & .000 & .000 & .000 \\
\hline & $\mathbf{N}$ & 148 & 148 & 148 & 148 & 148 & 148 & 148 & 148 \\
\hline \multirow{3}{*}{ IS } & $\begin{array}{l}\text { Pearson } \\
\text { Correlation }\end{array}$ & $.451(* *)$ & $.314(* *)$ & $.571(* *)$ & 1 & $.440(* *)$ & $.420(* *)$ & $.466(* *)$ & $.373(* *)$ \\
\hline & Sig. (2-tailed) & .000 & .000 & .000 & & .000 & .000 & .000 & .000 \\
\hline & $\mathbf{N}$ & 148 & 148 & 148 & 148 & 148 & 148 & 148 & 148 \\
\hline \multirow{3}{*}{ KS } & $\begin{array}{l}\text { Pearson } \\
\text { Correlation }\end{array}$ & $.361(* *)$ & $.292(* *)$ & $.458(* *)$ & $.440(* *)$ & 1 & $.281(* *)$ & $.276(* *)$ & $.182(*)$ \\
\hline & Sig. (2-tailed) & .000 & .000 & .000 & .000 & & .001 & .001 & .027 \\
\hline & $\mathbf{N}$ & 148 & 148 & 148 & 148 & 148 & 148 & 148 & 148 \\
\hline \multirow{3}{*}{ KC } & \begin{tabular}{|l} 
Pearson \\
Correlation
\end{tabular} & $.387(* *)$ & $.210(*)$ & $.564(* *)$ & $.420(* *)$ & $.281(* *)$ & 1 & $.582(* *)$ & $.632(* *)$ \\
\hline & Sig. (2-tailed) & .000 & .010 & .000 & .000 & .001 & & .000 & .000 \\
\hline & $\mathbf{N}$ & 148 & 148 & 148 & 148 & 148 & 148 & 148 & 148 \\
\hline \multirow{3}{*}{$\mathbf{E M}$} & $\begin{array}{l}\text { Pearson } \\
\text { Correlation }\end{array}$ & .119 & -.032 & $.393(* *)$ & $.466(* *)$ & $.276(* *)$ & $.582(* *)$ & 1 & $.577(* *)$ \\
\hline & Sig. (2-tailed) & .151 & .700 & .000 & .000 & .001 & .000 & & .000 \\
\hline & $\mathbf{N}$ & 148 & 148 & 148 & 148 & 148 & 148 & 148 & 148 \\
\hline \multirow{3}{*}{ OO } & $\begin{array}{l}\text { Pearson } \\
\text { Correlation }\end{array}$ & $.270(* *)$ & $.163(*)$ & $.517(* *)$ & $.373(* *)$ & $.182(*)$ & $.632(* *)$ & $.577(* *)$ & 1 \\
\hline & Sig. (2-tailed) & .001 & .048 & .000 & .000 & .027 & .000 & .000 & \\
\hline & $\mathbf{N}$ & 148 & 148 & 148 & 148 & 148 & 148 & 148 & 148 \\
\hline \multicolumn{10}{|c|}{ ** Correlation is significant at the 0.01 level (2-tailed). } \\
\hline & & 051 & ailed). & & & & & & \\
\hline
\end{tabular}


Table 3 Results of hypotheses testing using Pearson's correlation

\begin{tabular}{|l|l|l|}
\hline Hypotheses & Variables addressed & Pearson correlation \\
\hline$H 1$ & IS, OO & $.373(* *)$ \\
\hline$H 2$ & CM, OO & $.270(* *)$ \\
\hline$H 3$ & IS, KS & $.440(* *)$ \\
\hline$H 5$ & IS, KC & $.420(* *)$ \\
\hline$H 6$ & IS, EM & $.466(* *)$ \\
\hline$H 7$ & CM, KS & $.361(* *)$ \\
\hline$H 8$ & CM, KC & $.387(* *)$ \\
\hline$H 9$ & CM, EM & .119 \\
\hline$H 10$ & CT, CM & $.544(* *)$ \\
\hline$H 11$ & CB, CM & $.614(* *)$ \\
\hline$H 12$ & CT, OO & $.163(*)$ \\
\hline$H 13$ & CB, OO & $.517(* *)$ \\
\hline$H 14$ & CT, KS & $.292(* *)$ \\
\hline$H 15$ & CT, KC & $.210(*)$ \\
\hline$H 16$ & CT, EM & -.032 \\
\hline$H 17$ & CB, KS & $.458(* *)$ \\
\hline$H 18$ & CB, KC & $.564(* *)$ \\
\hline$H 19$ & CB, EM & $.393(* *)$ \\
\hline$H 20$ & KS, OO & $.182(*)$ \\
\hline$H 21$ & KC, OO & $.632(* *)$ \\
\hline E & EM, OO & $.577(* *)$ \\
\hline
\end{tabular}

** Correlation is significant at the 0.01 level (2-tailed). * Correlation is significant at the 0.05 level (2-tailed). $\mathrm{N}=148$. 


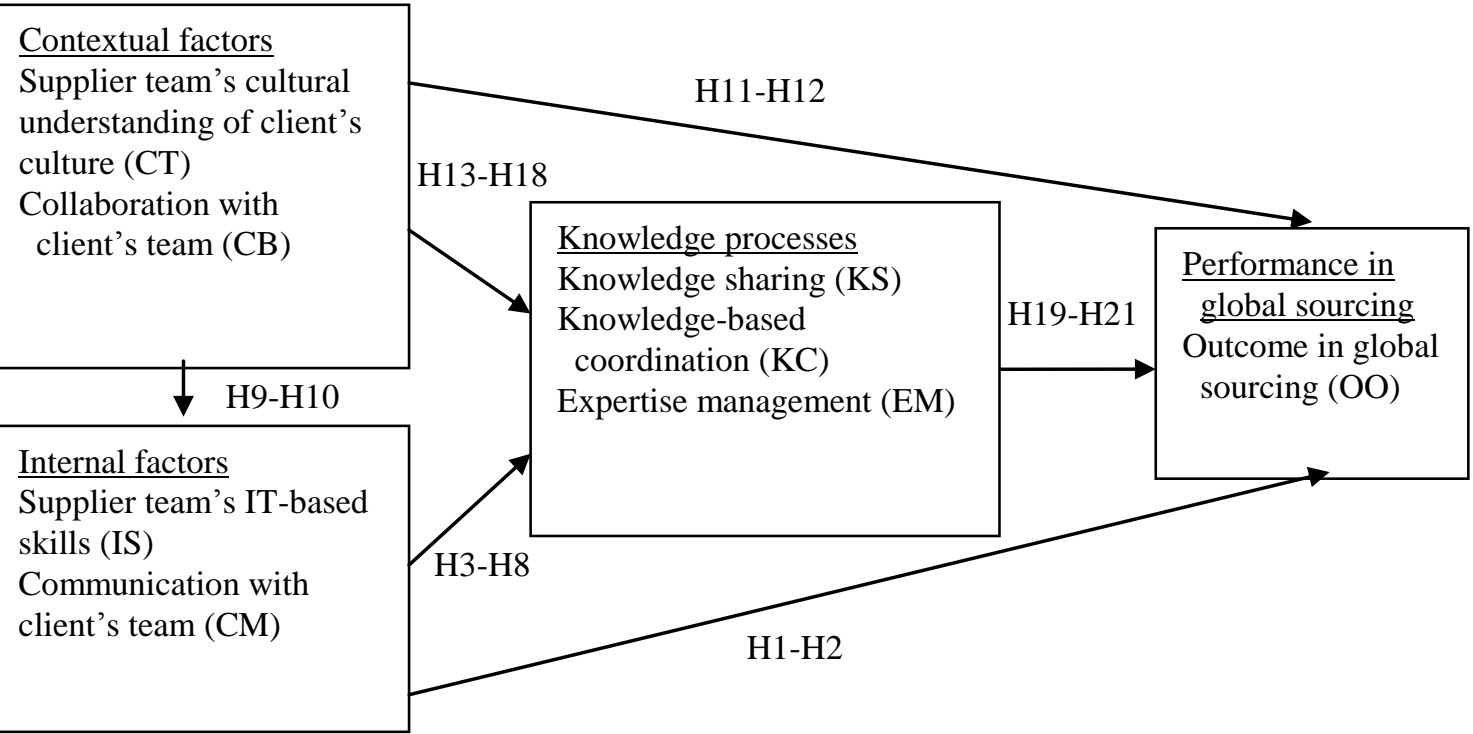

Fig. 1 Factors influencing knowledge processes and performance in global sourcing 